\title{
Mastitis-related subtypes of bovine Staphylococcus aureus are characterized by different clinical properties
}

\author{
H. U. Graber, ${ }^{* 1}$ J. Naskova, ${ }^{*}$ E. Studer, ${ }^{*}$ T. Kaufmann, ${ }^{*}$ M. Kirchhofer, ${ }^{*}$ M. Brechbühl, ${ }^{*}$ W. Schaeren, $\dagger$ \\ A. Steiner, ${ }^{*}$ and C. Fournier* \\ ${ }^{*}$ Clinic for Ruminants, Department of Clinical Veterinary Medicine, University of Berne, Bremgartenstrasse 109a, PO Box 8466 , \\ 3001 Berne, Switzerland \\ †Agroscope Liebefeld-Posieux, Swiss Federal Research Station for Animal Production and Dairy Products, Schwarzenburgstrasse 161, \\ 3003 Berne, Switzerland
}

\begin{abstract}
Based on a former study from our group, one subtype of Staphylococcus aureus was associated with high within-herd prevalence of mastitis, whereas the other subtypes were associated with a low prevalence (sporadic intramammary infection). To confirm this hypothesis, a prospective study was done in 29 Swiss dairy herds. In particular, milk samples were collected from 10 herds with Staph. aureus herd problems (cases) and compared with samples from 19 herds with only sporadic cases of with Staph. aureus intramammary infection (controls). The isolates were tested for their virulence gene pattern and genotyped by PCR amplification of the 16S-23S rRNA intergenic spacer. The patterns and genotypes were then associated and compared with epidemiological and clinical data. Confirming the hypothesis, one particular subtype (genotype B) was associated with high within-herd and within-cow prevalence of intramammary infection, whereas the other subtypes were associated with low within-herd prevalence and infected single quarters. The gene patterns and genotypes were highly related, demonstrating the genetic diversity of the genotypes. The somatic cell counts were clearly increased in herds with a genotype B problem compared with herds with infections of other genotypes. Based on the different clinical properties and treatment consequences associated with these different genotypes found in Switzerland, we recommend subtyping Staph. aureus in other countries to determine if this finding is universally applicable.
\end{abstract}

Key words: subtyping, mastitic, Staphylococcus aureus, diagnostics

\section{INTRODUCTION}

Staphylococcus aureus is one of the most important causes of chronic, clinical, or subclinical bovine masti-

Received June 6, 2008.

Accepted November 15, 2008.

${ }^{1}$ Corresponding author: hans.graber@knp.unibe.ch tis worldwide (IDF, 2005) and is associated with great economic losses (Seegers et al., 2003; Kirchhofer et al., 2007) in dairy herds.

In a previous study (Fournier et al., 2008) in Swiss cows, the authors found that Staph. aureus isolated from bovine IMI is a genetically heterogeneous group. By PCR amplification of the 16S-23S rRNA intergenic spacer region [ribosomal spacer (RS)-PCR], 17 genotypes were detected in 101 epidemiologically independent isolates. Two of the genotypes, genotype B (GTB) and genotype C (GTC), were common $(80.2 \%)$, whereas the other 15 genotypes (GTOG) occurred rarely, each accounting for 1.0 to $4.0 \%$ of all the isolates. The same study further demonstrated that the genotypes were highly associated with their virulence gene pattern (VGP). The corresponding patterns were obtained 1) by PCR-testing for the presence of the staphylococcal enterotoxin genes sea to sej and the tst gene (toxic shock syndrome toxin-1, TSST-1); 2) by evaluation for polymorphisms of the protein A (spa) and the coagulase (coa) genes (PCR); and 3) by searching for RFLP of the leukotoxin E gene (lukE). In particular, we found that GTB was characterized by the presence of the sea, sed, and sej genes, a long $\mathrm{x}$-region of $s p a$, and 3 lukE fragments. In contrast, GTC was positive for $s e c, s e g$, and tst, a short x-region of spa, and 2 lukE fragments. The GTOG were heterogeneous in their VGP. The same study (Fournier et al., 2008) further revealed remarkable differences in prevalences of IMI among the 3 genotypes. Considering GTB, up to $64.7 \%$ of cows in a herd were infected by strains of this genotype and $49 \%$ of the cows had more than 1 quarter infected. In the case of GTC and GTOG, however, IMI was found in 1 to 3 cows of a herd. In all cases, only one quarter within an udder of a cow was infected.

The staphylococcal enterotoxins (SET) and TSST-1 comprise a large family of proteins (Omoe et al., 2005) with superantigenic properties (Balaban and Rasooly, 2000). In cattle, they act as virulence factors (Chang et al., 2005) and induce, among other effects, the production of the interleukins 4 and 10, which leads to 
reduced clearance of microbial pathogens (Burton and Erskine, 2003). Protein A is associated with the cell wall and captures antibodies inhibiting opsonization of the pathogen repelling the host defense (Foster and McDevitt, 1994). Leukotoxin $\mathrm{E}$ is a component of the pore-forming leukocidins, which are cytotoxic for erythrocytes and leukocytes (Miles et al., 2001). Coagulase, an exoprotein, clots plasma fibrinogen by forming a complex with prothrombin (Panizzi et al., 2004).

Based on the study of Fournier et al. (2008), we assumed that the genotypes of Staph. aureus are contagious to varying degrees and that GTB accounts for herd problems, whereas GTC and GTOG are associated with sporadic IMI. The confirmation of this hypothesis would be of great clinical relevance to propose typespecific hygiene and treatment strategies in affected herds. To substantiate the above, we prospectively collected milk samples from herds with a Staph. aureus herd problem and compared them with those obtained from herds with sporadic Staph. aureus IMI. In addition, we analyzed inter- and intraherd variation of the staphylococcal VGP.

\section{MATERIALS AND METHODS}

\section{Herd Selection}

Based on the results of Fournier et al. (2008) and before starting the present study, we defined herds as Staph. aureus problem herds (case cohorts) if the quarter prevalence of Staph. aureus based on routine bacteriology (10- $\mu \mathrm{L}$ aliquot) was $\geq 10 \%$. Control cohorts were defined as herds with a quarter prevalence of Staph. aureus from 0 to $<10 \%$ (herds with sporadic IMI). The herds of both groups were spread over the western half of Switzerland (approximately 20,000 $\mathrm{km}^{2}$ ). Cow breed and herd size were irrelevant. A total of 10 problem (265 cows) and 19 control herds (257 cows) were included in the present study.

To analyze whether the genotypes of Staph. aureus obtained from a particular infected quarter changed over time, 8 quarters ( 8 cows) with subclinical mastitis caused by Staph. aureus were sampled on d 1, 2, 4 , and 7 . Another series of 13 quarters (10 cows) was tested twice -at d 1 and between d 12 and 16. The corresponding herds were newly selected and were not associated with the problem or control herds mentioned above.

\section{Sample Collection}

In each of the 29 herds investigated, all lactating cows were checked for udder health, including visual milk inspection and clinical examination of the udder and teats, with the teat ends judged as described by Mein et al. (2001). Subsequently, milk of each quarter was aseptically collected for bacteriological testing and analysis of SCC, and the lactation number $(\mathbf{L N})$ of each cow was recorded. The samples were transported and stored in the laboratory at $4^{\circ} \mathrm{C}$ and analyzed for SCC within $24 \mathrm{~h}$. Samples designed for bacteriology and PCR analysis were stored at $-20^{\circ} \mathrm{C}$ until further use.

\section{Staph. aureus Isolates}

From the problem and control herds, 1,057 and 1,023 milk samples, respectively, were bacteriologically analyzed $(10-\mu \mathrm{L}$ aliquots) using standard procedures as described by the National Mastitis Council (NMC, 1999). In particular, Staph. aureus and other mastitis pathogens such as CNS or Streptococcus spp. were identified including colony morphology, biochemical properties, and detection of hemolysis. The problem herds provided 276 Staph. aureus isolates and the control herds yielded 25 isolates. All the isolates were further checked by PCR (see below) for the presence of the nuc gene, which codes for thermonuclease and is known to be specific for Staph. aureus (Brakstad et al., 1992; Graber et al., 2007). Isolates lacking this gene were excluded from the present study.

\section{Extraction of Nucleic Acids}

A single colony of Staph. aureus was resuspended in $100 \mu \mathrm{L}$ of Tris-EDTA buffer $(10 \mathrm{mM}$ Tris/HCl, 1 $\mathrm{m} M$ EDTA, $\mathrm{pH} 8.0)$, incubated at $95^{\circ} \mathrm{C}$ for $10 \mathrm{~min}$ and placed immediately into ice. The resulting lysate was stored at $-20^{\circ} \mathrm{C}$ until further use. For RS-PCR, the lysate was diluted 1:100 in $\mathrm{H}_{2} \mathrm{O}$ and directly used for amplification. For all the remaining PCR, the lysate was purified: $30 \mu \mathrm{L}$ of lysate was added to $170 \mu \mathrm{L}$ of Tris-EDTA-sucrose buffer $(100 \mathrm{~m} M$ Tris/HCl, $10 \mathrm{mM}$ EDTA, 25\% sucrose (wt/vol), $\mathrm{pH} 8.0$ ) containing 0.5 mg of lysozyme (Merck, Berne, Switzerland) and $20 \mathrm{U}$ of mutanolysin (Sigma, Buchs, Switzerland) for $60 \mathrm{~min}$ at $37^{\circ} \mathrm{C}$. Total nucleic acid (NA) containing DNA and RNA was extracted using the High-Pure PCR Template Preparation Kit (Roche Diagnostics, Rotkreuz, Switzerland).

\section{Primers}

For nuc gene amplification, the primers of Graber et al. (2007) were applied, and for coa and spa, the primers of Akineden et al. (2001) were used. The SET genes sea, seb-sec, sec, sed, see, seg, seh, sei, and sej were amplified with the primers as described by Monday and Bohach (1999). For tst, we chose the primers according 
to Lovseth et al. (2004). Amplification of the lukE gene (coding for leukotoxin E) was done using the primers of Fournier et al. (2008). The G1 and L1 primers of Jensen et al. (1993) were used for genotyping.

\section{Gene Amplification and Genotyping}

Gene amplification and genotyping was performed as described by Fournier et al. (2008). In brief, the PCR reaction mix (total volume of $25 \mu \mathrm{L}$ ) for amplification of the nuc, coa, spa, and lukE genes contained $1 \times$ HotStarTaq Master Mix (Qiagen AG, Hombrechtikon, Switzerland), $300 \mathrm{n} M$ of each primer, and $2.5 \mu \mathrm{L}$ of the purified lysate NA. For each gene, the described PCR profile and the corresponding cycle numbers were used. The same was also true for tst amplification. For the detection of the SET genes, multiplex PCR assays $(25 \mu \mathrm{L})$ were conducted as reported by Fournier et al. (2008).

The RS-PCR method of Jensen et al. (1993) was used for genotyping; this method is based on PCR amplification of the $16 \mathrm{~S}-23 \mathrm{~S}$ rRNA intergenic spacer region. All details including ramping times are given in Fournier et al. (2008).

For the different PCR mentioned above, negative and positive controls were included in every run. For the negative control, $\mathrm{H}_{2} \mathrm{O}$ was added instead of NA. For positive controls, bovine Staph. aureus strains positive for the corresponding genes were used.

The PCR products of the nuc and lukE genes were analyzed by agarose gel electrophoresis in Tris-borateEDTA buffer (45 mM Tris-borate, $1 \mathrm{~m} M$ EDTA, pH 8.3). Gel staining was done by adding $6 \mu \mathrm{L}$ of the GelRed stock reagent (Biotium Inc., Hayward, CA) to 60 $\mathrm{mL}$ of hot gel solution. The stained gels were viewed using a standard transilluminator $(312 \mathrm{~nm})$. The PCR products of the 16S-23S rRNA intergenic spacer region, the SET genes, coa, and spa were analyzed by the miniaturized electrophoresis system DNA 7500 LabChip (Agilent Technologies, Basel, Switzerland). Interpretation of the $16 \mathrm{~S}-23 \mathrm{~S}$ rRNA intergenic spacer region results was performed according to Fournier et al. (2008).

Restriction enzyme analysis of $l u k E$ was performed as described by Fournier et al. (2008) using RsaI (Roche Diagnostics) for digestion of the lukE PCR product. Visualization was done by agarose electrophoresis $(1.8 \%$ agarose gel in Tris-borate-EDTA buffer) and GelRed stain.

\section{Analysis of Somatic Cells}

To analyze SCC, the milk samples were prewarmed at $37^{\circ} \mathrm{C}$ for $10 \mathrm{~min}$ before analysis. The somatic cells were then counted with a Fossomatic 5000 Integrated Milk Testing (Foss, Hillerød, Denmark).

\section{Statistical Analysis}

Data were expressed as mean \pm standard deviations, medians, minimum and maximum, frequencies, or percentages. Frequencies were analyzed by 2 -way tables using the Chi-square test. Medians were compared by the Mann-Whitney $U$ test. Uni- and multivariate analyses were performed to test whether problem and control herds differed in LN and teat scores, factors that may affect the presence of a GTB or GTC IMI.

Control and problem herds were analyzed to determine whether they differed in risk factors favoring an IMI caused by Staph. aureus. In this context it was shown by Zadoks et al. (2001) that parity and teat orifice hyperkeratosis with very rough rings were the 2 major risks. In the present study, the means of the LN between the control and problem herds were compared by the Mann-Whitney $U$ test. For the multivariate analysis, the orifice alterations were grouped into "very rough" and "others" (binary variable), and parity was treated as a categorical variable with 4 levels: the first 3 levels corresponded to $\mathrm{LN}=1$ to 3 , the fourth level included $\mathrm{LN} \geq 4$. For each of the control and problem group, herds were selected with a herd size $\geq 10$. For each herd, we then randomly chose 10 cows to rule out a bias due to different herd sizes. The multivariate risk factor analysis was done by logit regression with group as the dependent variable. Parity, orifice hyperkeratosis, and the corresponding interaction served as the independent variables. The model was compared with constants only model (null model) by the Wald likelihood ratio test.

To evaluate the SCC values between problem and control herds, the following procedure was applied: 1) for each cow, the mean $\log _{10}(\mathrm{SCC})$ of all quarters was calculated [cow $\log _{10}(\mathrm{SCC})$ value]; 2$)$ with these values, the herd mean was computed [composite $\log _{10}(\mathrm{SCC})$ value] for each of the problem and the control herds; and 3) the composite $\log _{10}(\mathrm{SCC})$ values between the problem and the control groups were then compared by the $t$-test using pooled variances. To further extend these comparisons and to estimate the fraction of $\log _{10}(\mathrm{SCC})$ variability explained by the chosen factors ("herd" and "group"), a balanced, nested 2-factor ANOVA was performed whereby factor "herd" was nested within "group" (problem/control group). Herd and animal selection was performed as described for risk factor analysis and was done irrespective of the cows' SCC. To test the fit of the ANOVA model, the fitted values were plotted against the observed ones and the residuals were checked for normal distribution 
by quantile-quantile plot and the Kolmogorov-Smirnov one-sample test assuming normal distribution.

Pathogenicity of the Staph. aureus GTB and GTC genotypes was compared as described by Fournier et al. (2008). In particular, quarters showing a corresponding monoinfection were used and for each genotype the mean $\log _{10}(\mathrm{SCC})$ were calculated and compared by the $t$-test using pooled variances. As an extension, $\log _{10}(\mathrm{SCC})$ was further analyzed by mixed regression with the genotypes as a fixed and the herds as a random variable.

The method of generalized estimating equations (GEE; Liang and Zeger, 1986) was used to compare the genotypes among themselves based on the analyzed genes as described previously (Fournier et al., 2008). If a Staph. aureus isolate showed a positive PCR result for a particular gene/polymorphism or an $R s a$ I restriction site, it was classified as present $(=1)$; otherwise it was considered as absent $(=0)$. For this study, 11 of these binary variables were included into the GEE analysis. The "virulence gene pattern" was the dependent variable using a within-subject correlation structure with identical ("exchangeable") coefficients. The genotype obtained by RS-PCR served as the independent variable. Furthermore, the binomial variance function was used. Computation was done by the "geepack" library of the R 2.4.1. statistical software package (R Development Core Team, 2008). For all the other statistical analyses, Systat 12 (Systat Software Inc., Richmond, CA) was applied. Significance was defined as values of $P<0.05$.

\section{RESULTS}

Staphylococcus aureus was observed in all problem and control herds of this study; the number of infected cows and quarters within an udder, however, differed markedly between the 2 groups (Table 1 ). Of the 10 farms with udder health problems caused by Staph. aureus, 127 of 265 cows (47.9\%) were positive for Staph. aureus in one or more quarters within an udder. At the cow level, minimal prevalence was 18.2\% (Figure 1), maximal prevalence was $87.5 \%$, and the median was $44.0 \%$. At the quarter level, 276 out of 1,057 samples (26.1\%) were positive for Staph. aureus. Minimal and maximal prevalence at the quarter level was 11.3 and $45.3 \%$, respectively (Figure 2); the median was $25.2 \%$. Of the 19 control farms, a total of 257 cows $(1,023$ quarters) were investigated. Of these, 25 cows $(9.7 \%)$ were positive for Staph. aureus. Minimal prevalence at the cow level was $4.0 \%$ (Figure 1). The maximum prevalence was $33.3 \%$ (extreme outlier) and the median was $9.1 \%$. At the quarter level, minimum and maximum prevalences of Staph. aureus were 1.0 and 8.3\%, respec- tively (Figure 2); the median was $2.5 \%$. As expected from the design of the present study, the farms with udder health problems and the control farms differed highly in their Staph. aureus prevalence, both at the cow and at the quarter levels $(P<0.001)$.

In problem herds, 122 (96.1\%) of the 127 Staph. aureus samples tested positive for GTB. Two were of type $\mathrm{C}$ and 3 of type OG. In 7 out of 10 herds, GTB was identified as the single Staph. aureus genotype (Table $1)$. In the 3 remaining herds, genotypes $\mathrm{C}$ (2 quarters), $\mathrm{P}$ (2 quarters), and $\mathrm{J}$ (1 quarter) were additionally detected. In these herds, GTB was always the predominant genotype (Figure 3).

All GTB strains were positive for a coa amplicon of $640 \mathrm{bp}$ and for one or both sea and sed genes (Table 2 ). Furthermore, there was a high association between the sed and sej gene: in 213 of 216 cases (98.6\%), both genes occurred simultaneously. The B genotypes were always negative for sec, seg, and sei. Restriction analysis of lukE revealed 3 fragments, and the size of the spa amplicon was $\geq 250 \mathrm{bp}$.

In control herds, GTC was found in 18 cases and OG types in 5 cases; GTB was never observed. All GTC strains were positive for seg and coa 640 (Table 2). The spa amplicon was $100 \mathrm{bp}$ and lukE digestion by $R s a \mathrm{I}$ produced 2 fragments. All strains were negative for sea, sed, and sej. The occurrence of sec, tst, and sei was inconsistent; sec and tst were always linked so that both of them were either present or lacking.

The VGP revealed obvious differences between GTB, GTC, and GTOG ( Table 2). To further confirm these results, the GTB and GTC groups were compared by the statistical GEE procedure. According to these computations, both genotypes differed in a highly significant manner $(P<0.001)$; GTOG was excluded from these analyses, because the corresponding sample size was very small $(\mathrm{n}=8)$ and a reliable statement was impossible.

At the quarter level, there was a clear association between observed genotypes and the group of herds $(P$ $<0.001)$. In particular, GTB was obviously associated with problem herds and GTC with control herds $(P<$ 0.001); GTOG was found both in problem and control herds, always at low frequencies (Table 1). The same associations were obtained if the quarter and the corresponding genotype prevalences were plotted for the problem and the control herds, as is depicted in Figure 3.

Uni- and multivariate analyses were performed to test whether problem and control herds differed in the cows' LN and teat scores, factors that may affect the presence of a GTB or GTC IMI. For the control group, the mean LN was 3.3 lactations (minimum $=1$ lactation, maximum $=9$ lactations); for the problem group, 
Table 1. Epidemiological data and herd-associated genotypes of Staphylococcus aureus and SCC at herd level

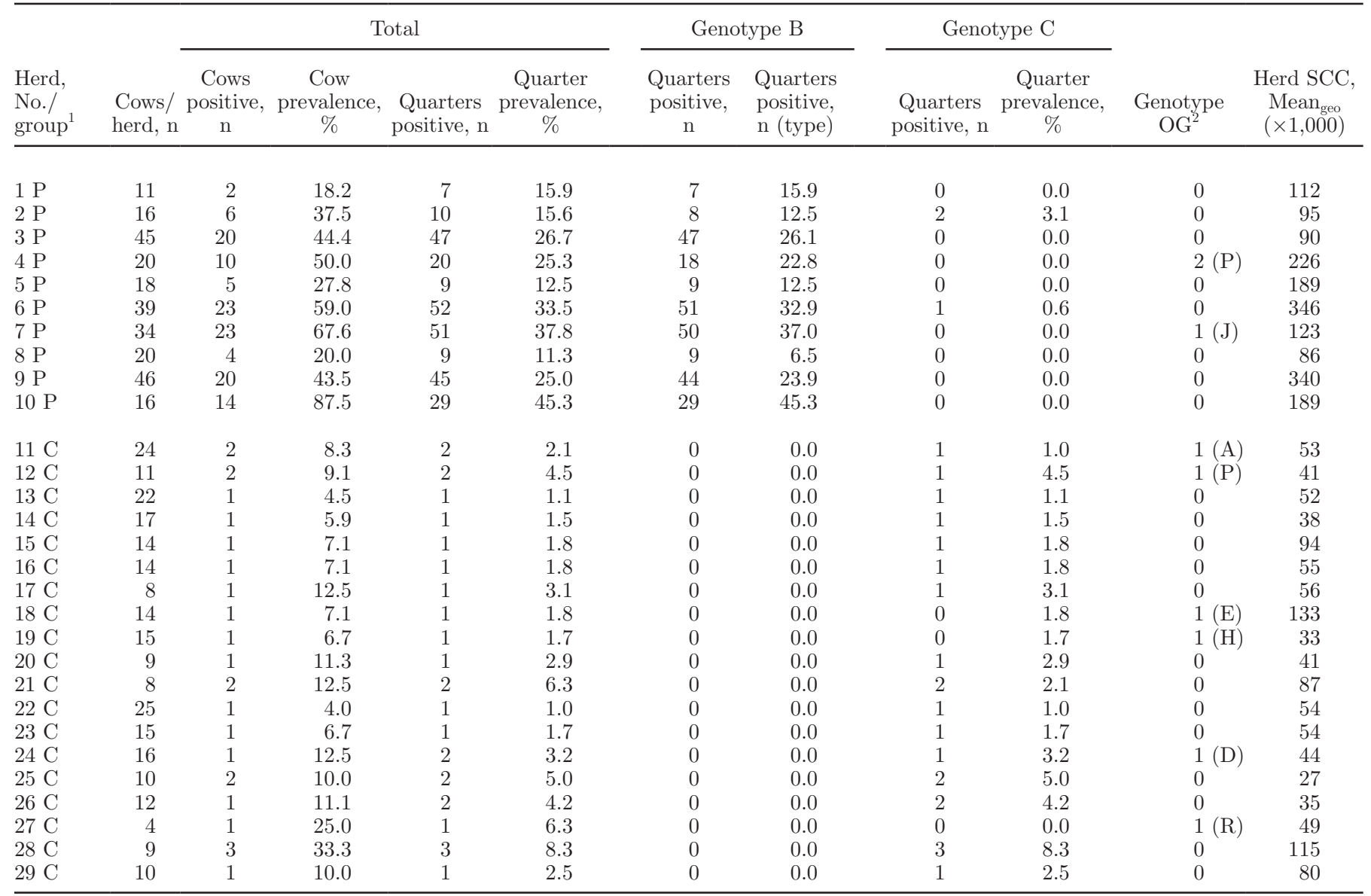

${ }^{1} \mathrm{P}=$ problem herds; $\mathrm{C}=$ control herds.

${ }^{2}$ Genotype $\mathrm{OG}=$ all the genotypes except genotype $\mathrm{B}$ and $\mathrm{C}$.

${ }^{3} \mathrm{Mean}_{\text {geo }}=$ geometric mean.

the mean LN was 2.9 lactations with a minimum of 1 and a maximum of 9 lactations $(P=0.239)$. In both groups, $25 \%$ of the cows were characterized by a LN $>4$. Considering the teat scores, there were 6 of 257 cows (14 quarters) of the control group with a very rough teat canal orifice. In problem herds, 1 of 265 cows (4 quarters) was observed with these changes. Analysis by the multivariate logit model revealed no evidence that the control and the problem herds differed in their teat scores $(P=0.478)$, LN $(P=0.592)$, or the corresponding interaction $(P=0.637)$. The same results were obtained when the model was compared with the constants only model (Wald's test: $P=0.586$ ).

Evaluation of the VGP of Staph. aureus in GTB herds revealed 3 types (VGP I to III), depending on the presence or absence of the sea, sed, or sej genes (Table 3). Interestingly, the state of the remaining SET genes (sec, seg, sei, tst) and of all the VGP (RFLP of lukE, size of the spa and coa amplicons) were identical for all isolates of the different herds. Type VGP I was characterized by the presence of all 3 SET genes (sea, sed, sej; Table 3), whereas VGP II lacked sea. Type VGP III was positive for sea, but negative for sed and sej. Type VGP II was most frequently observed. Considering intraherd variation, one single pattern was observed in 7 of 10 GTB herds. In 3 herds (herds 3, 5, and 7), 2 different types were detected (Table 3), whereby VGP I was always the predominant one. When these herds were analyzed for cows having 2 or more GTB infected quarters, the following results were obtained: in the case of herd 3,5 out of the 15 cows with multiple infections showed isolates that differed in their VGP (1 cow having 2 quarters infected with a VGP I and 2 quarters with a VGP III strain; 2 cows, each with 3 VGP I and 1 VGP III infected quarters; 2 cows, each having 1 quarter infected with a VGP I and a VGP III 


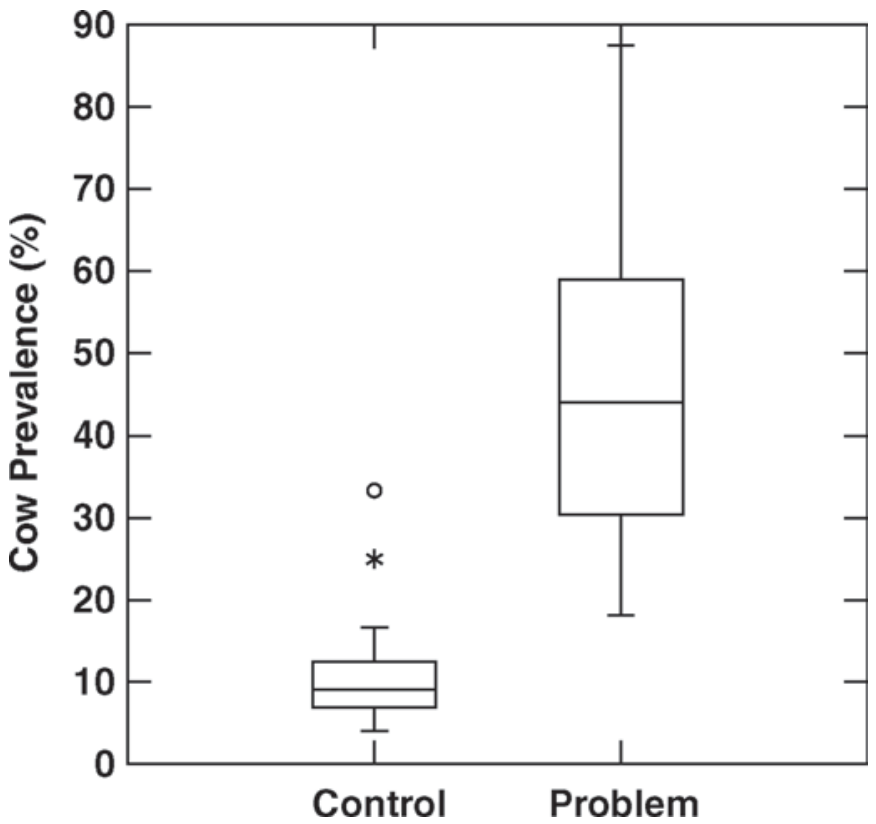

Figure 1. Cow prevalences of IMI observed in herds with a Staphylococcus aureus IMI problem (problem herds) and herds with sporadic occurrence of Staph. aureus IMI (control herds). There is a clear difference between the 2 medians $(P<0.001)$. ${ }^{*}=$ outlier; $\bigcirc=$ extreme outlier.

strain). Considering herds 5 and 7, there was 1 cow of 2 and 1 cow of 13 with multiple infections, respectively, showing IMI with different strains.

In a further study, we analyzed whether the genotypes of Staph. aureus obtained from a particular infected quarter changed over time. For this reason, 18 quarters with subclinical mastitis caused by Staph. aureus were sampled on different days and the isolates were genotyped. For each quarter, the corresponding genotype remained the same throughout the whole observation period. Thirteen strains were of GTB, 5 of GTC, and 3 of genotype P. We also determined whether the colonies on a particular agar plate were all of the same type. To do so, samples of 5 quarters mentioned above were plated out. A total of 15 Staph. aureus colonies per plate were then randomly selected and genotyped. For each plate, all the colonies were of the same type (GTB, GTC, and genotype P).

Comparison of the composite $\log _{10}(\mathrm{SCC})$ values between problem and control herds revealed, for the controls, a mean of $4.69 \log _{10}($ cells $/ \mathrm{mL})$ with an SD of 0.17 $\log _{10}($ cells $/ \mathrm{mL})$. For the problem group, the mean was $5.18 \log _{10}($ cells $/ \mathrm{mL})$ with an SD of $0.23 \log _{10}($ cells $/ \mathrm{mL})$. The group means clearly differed $(P<0.001)$. Analysis of variance with the factor "herd" nested within the factor "group" (problem/control herds) confirmed that $\log _{10}$ (SCC) was highly dependent on the group of herds $(P<0.001)$. Furthermore, ANOVA demonstrated that $\log _{10}(\mathrm{SCC})$ depended on the herd, irrespective of group classification of a particular herd $(P=0.007)$. The coefficient of multiple determination $\mathrm{R}^{2}$ was 0.364 .

Analysis of SCC for IMI caused by monoinfection with Staph. aureus revealed differences among the genotypes. For GTB $(\mathrm{n}=178)$, the mean $( \pm \mathrm{SD})$ composite $\log _{10}(\mathrm{SCC})$ value was $5.97 \pm 0.49 \log _{10}$ (cells/ $\mathrm{mL})$. There were 174 cows $(97.8 \%)$ with $\mathrm{SCC}$ values $>1.0 \times 10^{5}$ cells $/ \mathrm{mL} ; 4$ cows $(2.2 \%)$ showed lower values. In the case of GTC $(\mathrm{n}=13)$, the mean $( \pm \mathrm{SD})$ was $5.63 \pm 0.61 \log _{10}($ cells $/ \mathrm{mL})$. Eleven $(84.6 \%)$ cows were characterized by pathological SCC values $\left(>1.0 \times 10^{5}\right.$ cells $/ \mathrm{mL})$ and $2(15.4 \%)$ had normal values. The means differed significantly $(P=0.021)$. The same result was obtained when mixed regression analysis was applied $(P=0.036)$. This analysis further demonstrated that $\log _{10}(\mathrm{SCC})$ depended on the herd, irrespective of group classification of a particular herd $(P<0.001)$.

For herds infected with Staph. aureus GTB, the median prevalence for a calculated cow SCC value above $1.5 \times 10^{5}$ cells $/ \mathrm{mL}$ was $47 \%$ (minimum $=30 \%$; maximum $=74 \%$; Figure 4 ). For the control group, the median was $17 \%$ ( minimum $=0 \%$; maximum $=35 \%$ ). The difference of the 2 medians was highly significant $(P<0.001)$.

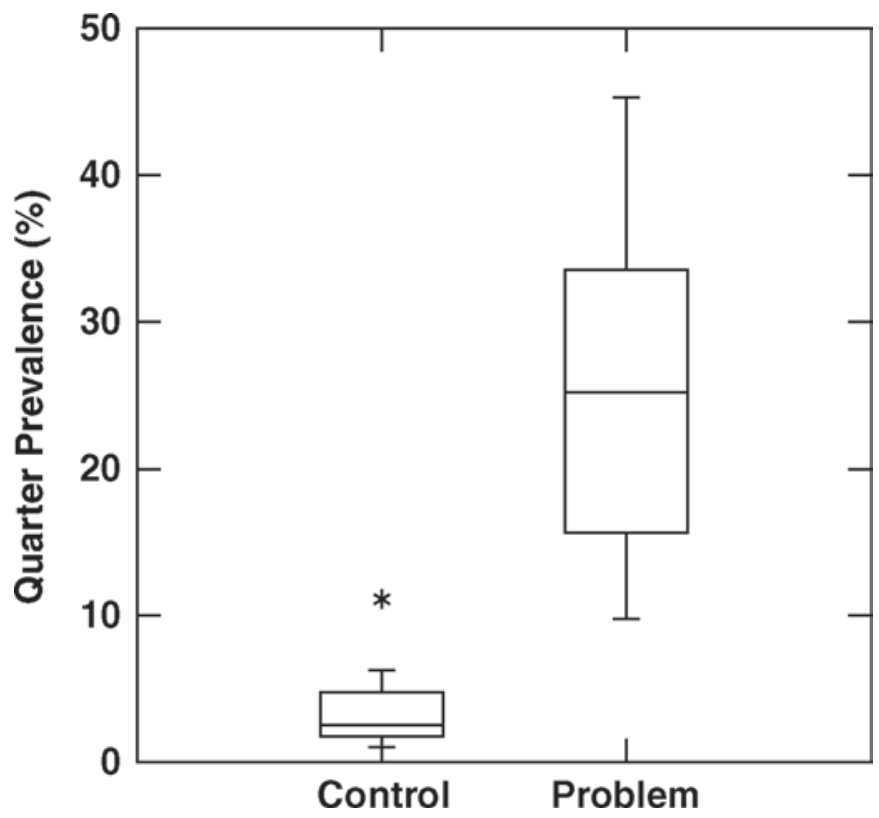

Figure 2. Quarter prevalences of IMI observed in herds with a Staphylococcus aureus IMI problem (problem herds) and herds with sporadic occurrence of Staph. aureus IMI (control herds). There is a clear difference between the 2 medians $(P<0.001){ }^{*}=$ outlier. 
Table 2. Distribution of virulence genes and their properties among genotypes B, C, and other genotypes (OG)

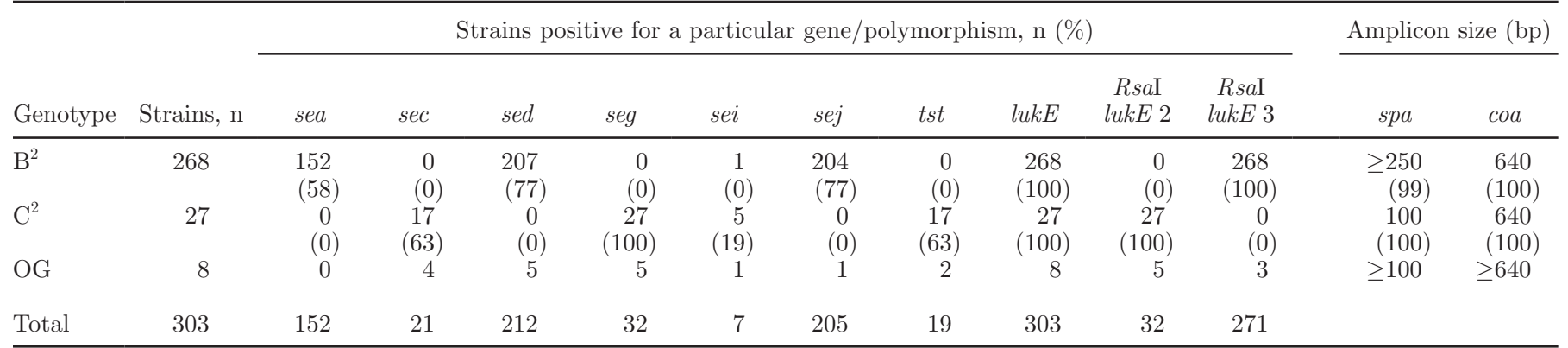

${ }^{1}$ All the Staphylococcus aureus strains were included which had been found both in problem and control herds. Genotype OG was not statistically compared with the genotype $\mathrm{B}$ and $\mathrm{C}$ because of its small sample size.

${ }^{2}$ The genotypes differ significantly $(P<0.001)$.

\section{DISCUSSION}

The present study clearly demonstrates that different subtypes (genotypes) of Staph. aureus found in Switzerland differ in their epidemiological properties. In particular, GTB was characterized by a high within-herd prevalence of IMI, whereas GTC and GTOG affected individual cows and quarters within a herd. In contrast to the descriptive study of Fournier et al. (2008), the present investigations are characterized by a prospective design, actively selecting herds with a real Staph. aureus problem (quarter prevalence of Staph. aureus obtained by routine bacteriology $\geq 10 \%$ ) and comparing them with herds with sporadic Staph. aureus IMI (quarter prevalence of Staph. aureus obtained by routine bacteriology $>0$ and $<10 \%)$. Although the design of both studies was different, the results coincided: GTB was associated with a high within-herd prevalence of IMI, whereas GTC and GTOG were related to low prevalence. The presence of a GTB or GTC IMI was neither influenced by different teat-end callosities of the

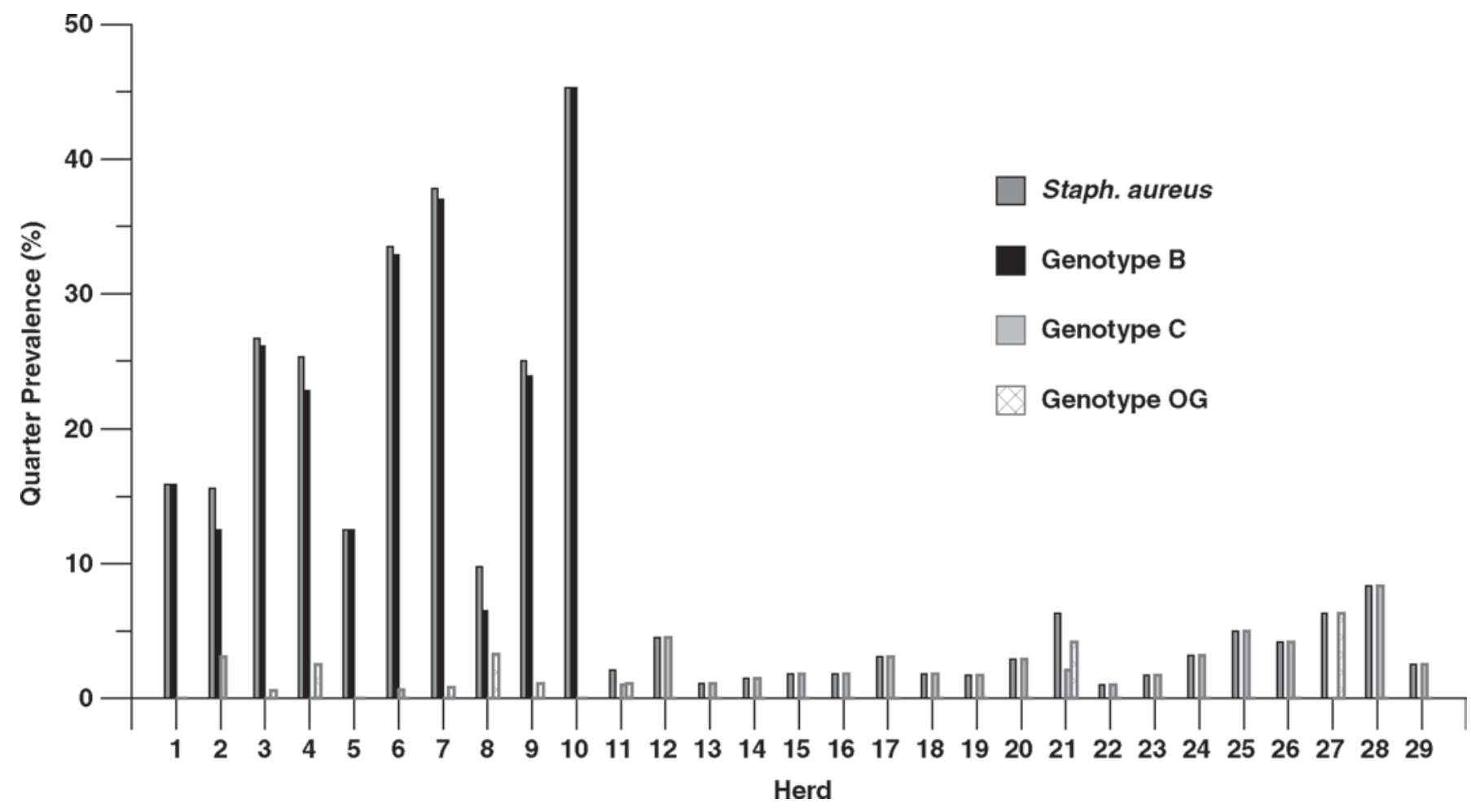

Figure 3. Quarter prevalences of IMI observed in herds with a Staphylococcus aureus IMI problem (herds 1 to 10) and herds with sporadic occurrence of Staph. aureus IMI (herds 11 to 29). Genotype B of Staph. aureus was observed exclusively in herds with problems of Staph. aureus IMI. Genotype C and other genotypes (genotype OG) were the pathogens primarily observed in herds with sporadic IMI. There is a clear difference between prevalences of problem and control herds. 
Table 3. Staphylococcus aureus of genotype B (GTB): virulence gene patterns (type I to III) between and within problem herds

\begin{tabular}{|c|c|c|c|c|c|c|c|c|c|c|c|c|c|}
\hline Herd no. & Isolates, $\mathrm{n}$ & Isolates, \% & $\begin{array}{l}\text { GTB } \\
\text { pattern } \\
\text { type }\end{array}$ & \multicolumn{10}{|c|}{ Gene } \\
\hline 2 & 8 & 100 & II & - & - & + & - & - & + & - & + & + & + \\
\hline $3 a$ & 34 & 71 & I & + & - & + & - & - & + & - & + & + & + \\
\hline $3 b$ & 14 & 29 & III & + & - & - & - & - & - & - & + & + & + \\
\hline $6 \mathrm{a}$ & 45 & 94 & $\mathrm{I}$ & + & - & + & - & - & + & - & + & + & + \\
\hline $6 \mathrm{~b}$ & 3 & 6 & II & - & - & + & - & - & + & - & + & + & + \\
\hline 7 & 49 & 100 & II & - & - & + & - & - & + & - & + & + & + \\
\hline 8 & 6 & 100 & II & - & - & + & - & - & + & - & + & + & + \\
\hline 9 & 46 & 100 & III & + & - & - & - & - & - & - & + & + & + \\
\hline 10 & 29 & 100 & II & - & - & + & - & - & + & - & + & + & + \\
\hline
\end{tabular}

${ }^{1}$ sea, sec, sed, seg, sei, sej = staphylococcal enterotoxin genes; tst = gene of the toxic shock syndrome toxin- $1 ; R s a \mathrm{I} l u k E 3=\operatorname{digestion}$ of the lukE PCR amplicon by $R s a \mathrm{I}$ generated 3 fragments; lukE = leukotoxin E, a leukocidin component; spa, co = genes of protein A and coagulase, respectively.

infected cows $(P=0.543)$ nor by different parities $(P$ $=0.580)$ nor could it be explained by the interaction of the 2 variables $(P=0.648)$. Consequently, confounding of our results by these important Staph. aureus-specific risk factors (Zadoks et al., 2001) can be disregarded, meaning that the different within-herd prevalences of IMI observed with GTB and GTC/GTOG are largely

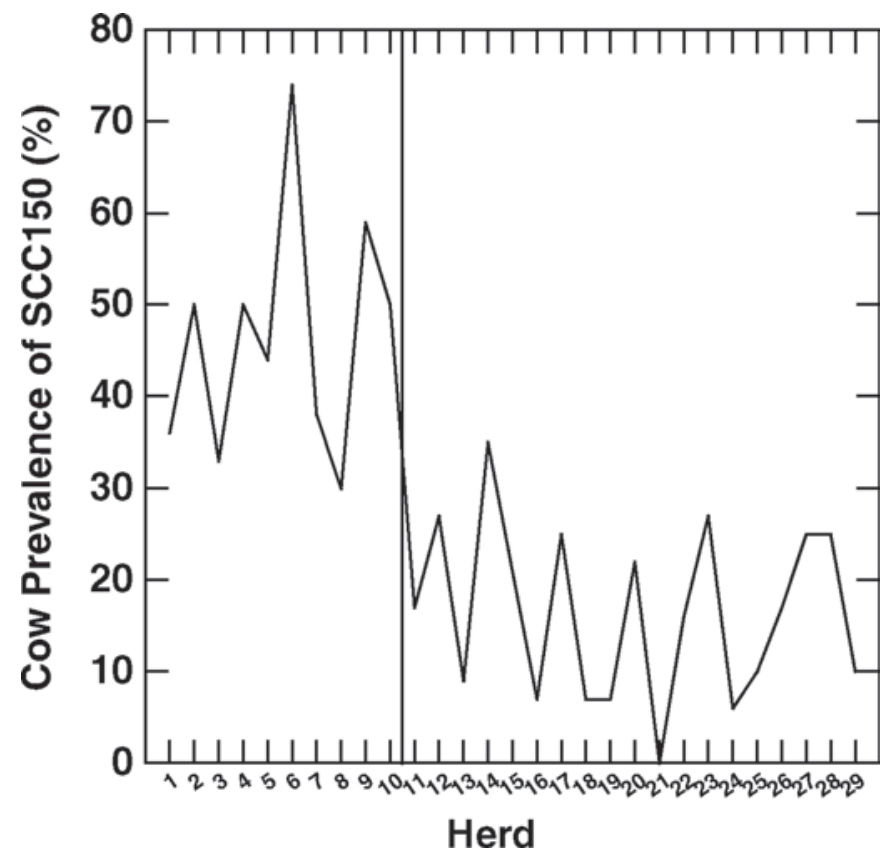

Figure 4. Prevalence of cows with a calculated cow SCC value $>1.5 \times 10^{5}$ cells $/ \mathrm{mL}$ (SCC150). Herds with a Staphylococcus aureus IMI problem (herds 1 to 10) are characterized with cow prevalences $\geq 30 \%$, whereas herds with sporadic Staph. aureus IMI are characterized by prevalences $<30 \%$ (except herd 14 ). caused by the different biological properties of the subtypes.

Because of the different epidemiological properties of the genotypes, different treatment strategies are indicated. Considering IMI with GTB, sanitation of the whole herd is necessary, which is an expensive and long-lasting procedure (about 1 yr; e.g., Kirchhofer et al., 2007). In the case of the other genotypes, however, only the infected cows need to be considered, a situation that is much more beneficial for the farmer than complete herd sanitation.

The next question is whether our findings are only restricted to Switzerland or whether they are universally applicable. To answer this question, IMI-associated Staph. aureus of other geographic areas need to be subtyped. At least in Switzerland, however, bovine Staph. aureus is no longer just "Staph. aureus."

The VGP presented in Table 2 revealed obvious differences between the genotypes and are in full accordance with those of the former study (Fournier et al., 2008). Genotype B was characterized by the presence of the SET genes sea, sed, and sej, 3 restriction fragments of $l u k E$ and a long x-region of spa $(\geq 250 \mathrm{bp})$. In contrast, GTC was positive for seg, 2 lukE fragments, and a short $\mathrm{x}$-region (100 bp). The occurrence of sec, sei, and tst was inconsistent, with a perfect association between sec and tst. The observed close association between GTB, GTC, and their VGP could further be confirmed by the statistical GEE analysis $(P<0.001)$. Type GTOG was of low frequency and its VGP was heterogeneous.

The genotype found in milk of a resampled quarter over time remained consistent throughout the whole observation period of 1 to $2 \mathrm{wk}$, demonstrating a persistent IMI with the identical strain. The shed amount 
of Staph. aureus, however, changes daily as shown by Studer et al. (2008) using quantitative real-time PCR. As a consequence for milk sampling, the actual genotype of Staph. aureus will always be isolated, independent of the shed amount of the pathogen.

Among herds with a GTB problem, 3 VGP were observed depending on the presence or absence of sea, sed, or sej. In 7 of the 10 herds, only 1 VGP was found. In the 3 remaining, 2 different types were detected, of which VGP I was always the predominant one. According to Le Loir et al. (2003), all the known SET genes are located on mobile genomic elements of Staph. aureus. In particular, sed and sej are part of the plasmid pIB485 and are separated by a short intergenic region of less than $1 \mathrm{kbp}$ (Zhang et al., 1998) explaining the very high association $(98.6 \%)$ between the 2 genes observed in the present study. The sea gene is carried by a family of temperate bacteriophages whose genomes incorporate and replicate with that of Staph. aureus (Balaban and Rasooly, 2000; Le Loir et al., 2003). Type VGP I was characterized by the presence of all 3 GTB-typical SET genes (sea, sed, and sej). Types VGP II and III, however, were negative for 1 or 2 of those genes. Considering herds with 2 different VGP, our results suggest that the common ancestor pathogen initially introduced into the herd was of VGP I but transfer of the mobile elements to its descendants was partially incomplete. The same phenomenon probably accounts for the finding that different quarters of a multiply infected cow may show different VGP.

In problem herds, the mean SCC of $5.18 \log _{10}$ (cells/ $\mathrm{mL}$ ) was considerably higher than in control herds [4.69 $\log _{10}($ cells $\left./ \mathrm{mL})\right]$ as shown both by the univariate and the ANOVA method (for both analyses $P<0.001$ ). The GTB herds were further characterized by a high number of cows with pathologically increased cow SCC $\left(\geq 1.5 \times 10^{5}\right.$ cells $\left./ \mathrm{mL}\right)$ ranging between 30 and $74 \%$ with a median of $47 \%$. This was in clear contrast to the control herds $(P<0.001)$ with pathological cow SCC between 0 and $35 \%$ (median $=17 \%$ ). These results demonstrate that the increased number of IMI observed in GTB herds was actually associated with an increased number of cows showing an intramammary inflammatory response. Indeed, 97.8\% $(\mathrm{n}=174)$ of quarters with a GTB monoinfection showed pathological SCC values $\left(>1.0 \times 10^{5}\right.$ cells $\left./ \mathrm{mL}\right)$, demonstrating that IMI with Staph. aureus GTB is actually associated with intramammary inflammation, a clear pathological state. In addition, there was an increased SCC in GTB monoinfected quarters compared with GTC monoinfections $(P=0.036)$. The difference, however, was rather moderate with a mean of $5.97 \log _{10}($ cells $/ \mathrm{mL})$ for GTB and $5.63 \log _{10}($ cells $/ \mathrm{mL})$ for GTC, respectively. Nevertheless, these results suggest some increased pathogenic potential of GTB strains. Again, the SCC results of the present prospective study fully coincide with those of the descriptive study done by Fournier et al. (2008).

For clinical purposes, a GTB problem in Swiss dairy herds is suspected if one or more of the following characteristics are detected: 1) the quarter prevalence of Staph. aureus obtained by routine bacteriological milk testing is $>10 \%$ or, similarly, the corresponding cow prevalence is $>18 \%$ (for a herd size $\geq 10$ cows); 2 ) the within-herd prevalence of cow SCC exceeding $1.5 \times 10^{5}$ cells $/ \mathrm{mL}$ is $\geq 30 \%$. The given values, however, are just indicators requiring confirmation by RS-PCR genotyping of corresponding Staph. aureus isolates. This methodology is quick, compelling, and cost-effective, allows a high throughput, and is, therefore, ideal for clinical purposes. Furthermore, it reflects the genetic and genomic diversities of bovine Staph. aureus as demonstrated by VGP analyses.

\section{CONCLUSIONS}

The present study confirms that subtypes (genotypes) of Staph. aureus with different epidemiological properties do exist in Switzerland. Subtype GTB is associated with a high within-herd prevalence of IMI, whereas GTC and GTOG are related to low withinherd prevalence. The genotypes are highly associated with specific VGP, demonstrating the genetic diversity of the genotypes. Somatic cell count is clearly increased in GTB herds compared with non-GTB herds and is also influenced by unknown farm-specific factors. Genotyping of Staph. aureus by the RS-PCR method is recommended, because the various Staph. aureus subtypes clearly differ in their epidemiological and, to a lesser extent, pathogenic properties, requiring separate measures for treatment and eradication.

\section{ACKNOWLEDGMENTS}

We thank D. Dietrich, Institute of Mathematical Statistics and Actuarial Science, University of Berne, Switzerland, for the critical review of the statistical results. The study was supported by grants of the Department of Clinical Veterinary Medicine, University of Berne, Switzerland.

\section{REFERENCES}

Akineden, O., C. Annemüller, A. A. Hassan, C. Lämmler, W. Wolter, and M. Zschöck. 2001. Toxin genes and other characteristics of Staphylococcus aureus isolates from milk of cows with mastitis. Clin. Diagn. Lab. Immunol. 8:959-964.

Balaban, N., and A. Rasooly. 2000. Staphylococcal enterotoxins. Int. J. Food Microbiol. 61:1-10.

Brakstad, O. G., K. Aasbakk, and J. A. Maeland. 1992. Detection of Staphylococcus aureus by polymerase chain reaction amplification of the nuc gene. J. Clin. Microbiol. 30:1654-1660. 
Burton, J. L., and R. J. Erskine. 2003. Immunity and mastitis. Some new ideas for an old disease. Vet. Clin. North Am. Food Anim. Pract. 19:1-45.

Chang, B. S., G. A. Bohach, S. U. Lee, W. C. Davis, L. K. Fox, W. A. Ferens, K. S. Seo, H. C. Koo, N. H. Kwon, and Y. H. Park. 2005. Immunosuppression by $\mathrm{T}$ regulatory cells in cows infected with staphylococcal superantigen. J. Vet. Sci. 6:247-250.

Foster, T. J., and D. McDevitt. 1994. Surface-associated proteins of Staphylococcus aureus: their possible roles in virulence. FEMS Microbiol. Lett. 118:199-205.

Fournier, C., P. Kuhnert, J. Frey, R. Miserez, M. Kirchhofer, T. Kaufmann, A. Steiner, and H. U. Graber. 2008. Bovine Staphylococcus aureus: Association of virulence genes, genotypes and clinical outcome. Res. Vet. 85:439-448.

Graber, H. U., M. G. Casey, J. Naskova, A. Steiner, and W. Schaeren. 2007. Development of a highly sensitive and specific assay to detect Staphylococcus aureus in bovine mastitic milk. J. Dairy Sci. 90:4661-4669.

IDF. 2005. Economic consequences of mastitis. Bull. Int. Dairy Fed. 394. IDF, Brussels, Belgium.

Jensen, M. A., J. A. Webster, and N. Straus. 1993. Rapid identification of bacteria on the basis of polymerase chain reaction-amplified ribosomal DNA spacer polymorphisms. Appl. Environ. Microbiol. 59:945-952.

Kirchhofer, M., L. Tavel, D. Strabel, C. Fournier, A. Steiner, H. U. Graber, and T. Kaufmann. 2007. Herd problem: Udder health. Retrospective study of farms with udder health problems assessed by the Swiss Bovine Health Service (BHS) from 1999 to 2004. Dtsch. Tierarztl. Wochenschr. 114:338-344.

Le Loir, Y., F. Baron, and M. Gautier. 2003. Staphylococcus aureus and food poisoning. Genet. Mol. Res. 2:63-76.

Liang, K. Y., and S. L. Zeger. 1986. Longitudinal data analysis using generalized linear models. Biometrika 73:13-22.

Lovseth, A., S. Loncarevic, and K. G. Berdal. 2004. Modified multiplex PCR method for detection of pyrogenic exotoxin genes in staphylococcal isolates. J. Clin. Microbiol. 42:3869-3872.

Mein, G. A., F. Neijenhuis, W. F. Morgan, D. J. Reinemann, J. E. Hillerton, J. R. Baines, I. Ohnstad, M. D. Rasmussen, L. Timms,
J. S. Britt, R. Farnsworth, and N. Cook, and T. Hemling. 2001. Evaluation of bovine teat condition in commercial dairy herds: 1. Non-infectious factors. Pages 344-351 in Proc. 2nd Int. Symp. Mastitis and Milk Quality, NMV/AABP, Vancouver, Canada. National Mastitis Council Inc., Madison, WI

Miles, G., S. Cheley, O. Braha, and H. Bayley. 2001. The staphylococcal leukocidin bicomponent toxin forms large ionic channels. Biochemistry 40:8514-8522.

Monday, S. R., and G. A. Bohach. 1999. Use of multiplex PCR to detect classical and newly described pyrogenic toxin genes in staphylococcal isolates. J. Clin. Microbiol. 37:3411-3414.

NMC. 1999. Laboratory Handbook on Bovine Mastitis. Rev. ed. National Mastitis Council Inc., Madison, WI.

Omoe, K., D. L. Hu, H. Takahashi-Omoe, A. Nakane, and K. Shinagawa. 2005. Comprehensive analysis of classical and newly described staphylococcal superantigenic toxin genes in Staphylococcus aureus isolates. FEMS Microbiol. Lett. 246:191-198.

Panizzi, P., R. Friedrich, P. Fuentes-Prior, W. Bode, and P. E. Bock. 2004. The staphylocoagulase family of zymogen activator and adhesion proteins. Cell. Mol. Life Sci. 61:2793-2798.

R Development Core Team. 2008. R: A language and environment for statistical computing. R Foundation for Statistical Computing, Vienna, Austria.

Seegers, H., C. Fourichon, and F. Beaudeau. 2003. Production effects related to mastitis and mastitis economics in dairy cattle herds. Vet. Res. 34:475-491.

Studer, E., W. Schaeren, J. Naskova, H. Pfaeffli, T. Kaufmann, M. Kirchhofer, A. Steiner, and H. U. Graber. 2008. A longitudinal field study to evaluate the diagnostic properties of a QPCR based assay to detect Staphylococcus aureus in milk. J. Dairy Sci. 91:1893-1902.

Zadoks, R. N., H. G. Allore, H. W. Barkema, O. C. Sampimon, G. J. Wellenberg, Y. T. Gröhn, and Y. H. Schukken. 2001. Cow- and quarter-level risk factors for Streptococcus uberis and Staphylococcus aureus mastitis. J. Dairy Sci. 84:2649-2663.

Zhang, S., J. J. Iandolo, and G. C. Stewart. 1998. The enterotoxin D plasmid of Staphylococcus aureus encodes a second enterotoxin determinant (sej). FEMS Microbiol. Lett. 168:227-233. 